\title{
The concept of human
} dignity in Cuba's legal and socio-political reality

\section{O conceito de dignidade} humana na realidade jurídica e sociopolítica de Cuba

\section{Sultan Hamade ${ }^{1}$} Karin Reiber ${ }^{2}$ 
Abstract: This article aims at giving a detailed explanation of the abstract notion of human dignity in the Cuban revolution. It takes into account both legal and socio-political aspects in order to provide a full picture of the subject. The article has a short historical background as a starting point, in which it will be explained how José Martí's ${ }^{3}$ words, that are part of the Constitution's Preamble, were embedded in the Constitution of 1976. Amongst the three most prominent heroes of revolutionary Cuba are (A\&E TELEVSION NETWORKS, 2018): José Martí, Ernesto Ché Guevara and Fidel Castro Ruz ${ }^{4}$, therefore, some explanation will be given on their notion of dignity, too. Furthermore, it describes how the concept of human dignity is interpreted and how it is implemented by the Cuban revolutionary government and judicial system. The article comes to the conclusion that there are three ways in which Cuba has implemented Martí's notion of dignity: through the principles of sovereignty, equality and the development of an alternative political system.

Keywords: Cuba; Human dignity; José Martí; Marxism; Fidel Castro.

Resumo: Este artigo aponta a dar uma explicação detalhada da noção abstrata da dignidade humana e da revolução cubana. Ele tem em conta aspetos legais e sócio-políticos que dãouma imagem completa do tema. $\mathrm{O}$ artigo tem um breve antecedente histórico como ponto de partida, onde se explica como as palavras de José Martí, são parte do preâmbulo da Constituição, incorporadas em nesta no 1976. Entre os três heróis mais importantes da revolução cubana se encontram José Marti, Ernesto Che Guevara e Fidel Castro Ruz, portanto, será dada uma explicação de sua noção de dignidade também. Além disso, será explicado como o conceito de dignidade humana é interpretado e executado pelo governo revolucionário de Cuba e do sistema judicial. O artigo afirma que existem três maneiras em que Cuba tem implementado noção de dignidade de Marti: através dos princípios de soberaia, igualdade e desenvolvimento de um sistema político alternativo.

Palavras-chave: Cuba; Dignidade Humana; José Martí; Marxismo; Fidel Castro. 


\section{Historical Background}

The victory of the Cuban revolution in 1959 marked a new era for the country's socio-political identity. Shortly after several dramatically tense events, the leader of the $26^{\text {th }}$ of July movement, Fidel Castro announced the Marxist-Leninist nature of the revolution (LEVECHENKO, 1963, p. 13). Since then, the state's constitution declares that Cuba is a socialist state led by a "Marxist-Leninist Martían" political party. The First constitutional amendment was officially introduced in 1976 after having been discussed in the first congress of the Cuban communist party (MOLINA, 2016, p. 166). The 1976 constitution was again modified after the collapse of socialist Bloc in 1992 and in 2002 with several changes in the precontext of its ideological language. However, in all of its modified versions, the constitution firmly highlights the concept of human dignity and social justice. In several constitutional articles, José Martí is quoted with references to human dignity, while further explanations of the constitution are based on the preexisting synergies of Martí's and Marxist-Leninist concepts of human dignity. Likewise, the Cuban revolutionary government believed that including Martían concepts of human dignity coincides with its new social project of constructing socialism. In addition, it raised the slogan of preserving human dignity that Jose Martí anticipated and fought for. In its further detailed explanations of the constitution, the government declares: Only in a socialist system is it possible to preserve human dignity (CONSEJO DEL PARTIDO COMUNISTA DE CUBA, 1974). Therefore, the following sections will be dedicated to understanding the Marxist logic of human dignity and its Cuban revolutionary interpretations; moreover, the reasons behind the amalgamation of Martían and Marxist principles of human dignity and equality will be discussed.

\section{Human Dignity and Marxism}

The appraisals of Marxism are still trapped by cold war anti-Soviet criticism. To be more precise, Marxism is linked with the oppression of the authoritarian state and Stalinist practices. Altogether, historical materialism is reduced to a simple militant dogma that only seeks to dominate and destroy individuals (BYRON, 2012, p. 16). Another myopia that academics suffer from, is declaring that Marx and Lenin barley tackled subjects of human rights and human dignity. As Van Herpen (2012, p. 16) argues: "Marx ignores the great merit of human 
rights"; moreover, "Marx only views human rights as a proclamation of the rights of the egoistical bourgeoisie”. Definitely historical materialism provides a deeper understating of human nature, human rights and social relations. However before expanding the view of historical materialism and dialectical materialism on such matters, it is important to note that Marx used a lot of synonymous and interchangeable vocabulary to tackle issues of human nature and rights (BYRON, 2012, p. 20). The same could be said about Lenin. Analyzing his sophisticated language in several of his writings leads us to his concrete interpretations concerning dignity, individuals and rights.

The concept of human dignity in Marxism is derived from a class equality perception. History and society are considered as a contentious progress of contradicting motion; furthermore, at a certain historical moment, such progress is interrupted by contradicting socio-economic factors that result in social and political changes (NOVACK, 1979, p. 37). The modes of production convert into an active force that transforms society and human relations. They create new social forces based on the ownership of production modes (EMRAKOVA; VOLKOV, 1986, p. 16). Marxism identifies five fundamental historical socio-economic formations: Primitive communal society, slavery, feudalism, capitalism and socialism (EMRAKOVA; VOLKOV, 1986, p. 20). Historically, the development of new modes of production and the shift in their ownership, managed to eliminate the social structure of the antique slavery society; nevertheless, capitalism managed to obliterate feudalism as a historical necessity since feudalism had contradicted with the development of capitalist socio-economical elements. According to Karl Marx the bourgeois state cannot provide a humanistic structure for society. In addition, the modern capitalist state pictures itself as the guardian of human dignity and freedom; however, in reality social relationships are dominated by private property and the greed for profit. It only provides human freedom that affiliates with its economic commercial nature of private property only as a right of egoistic individuals (CORNU, 1967, p. 682). Besides, the modern capitalist state views human dignity from an idealist metaphysical perspective; nevertheless, it only aims to preserve the state capitalist industrial hierarchy of exploitation (CORNU, 1967, p. 682). In “The Holy Family Critique of Critical Criticism" Marx points out to the undignified practices and exploitation that the proletariat suffers from; likewise, he explains how this marginalized class lives in inhumane conditions under capitalist exploitation. From a Marxist point of view, during the era of capitalist development and struggle against feudalism in Europe; human dignity was translated as a juridical equality 
among all individuals in front of the law. However, this does not guarantee a superior value of human dignity because it does not protect individuals from class hostility and exploitation (RUMIANSTEV, 1981, p. 189). Antonio Gramsci argues that human dignity should not be viewed only from the boundaries of the pre-existing social system ${ }^{5}$. Accordingly, only a radical social transformation that eliminates class oppression can provide a superior value of human dignity and equality (PALOS; GONZALEZ, 1984, p. 15).

The opponents of the Marxist concepts debate that Marxism aims towards the annihilation of civil society; moreover, individual interest could never be brought into a complete human harmony with collective interest. Conversely, Vladimir Lenin argued that the destruction of the existing state means: the destruction of all organized violence of the system against the individual and his/her human dignity; Furthermore, the elimination of exploitation of privileged individuals against other individuals (LENIN, 1977, p. 78).

From a Gramscian point of view, communism should respect civilization; moreover, it should aim for a system that will acquire a new form of human dignity and culture (FORGACS, 2000, p .21). This new form should be without any spiritual hierarchies, prejudices, idols and ossified traditions (FORGACS, 2000, p. 74). Such transition should be led by an educative determinative role of the state to improve the economic conditions of individuals so they can think in a collective approach instead of an individualist egoist manner (FORGACS, 2000, p. 116). While in Paulo Freire's abstract notion of human dignity, it is necessary to abolish the circle of oppression between the oppressed and the oppressor; nevertheless, after class oppression is terminated a new educative culture should be created to eliminate the circle of violence among the oppressed and the former oppressor (FREIRE, 2005, p. 175).

\section{José Martí and the Cuban revolution}

Without doubts, the Cubans aimed at giving their revolution an authentic national identity rather than a Soviet satellite portrait. In this case, no one better than Jose Martí could fulfill such a duty. Thus, Martí is considered to be the founder of Cuban modern identity. Since his early adolescent years, he started his struggle against the Spanish colonists in Cuba. Martí was subject to political imprisonment, forced labor and exile (DE ARMAS, 2003, p. 6). Along with Simon Bolívar, José Martí is considered to be one of the heroic icons in Latin-America for the struggle of independence and de-colonization; moreover, 
he is portrayed as the heroic philosopher, poet and writer who carried up arms for the war of independence and was martyred at the age of 45 in the battle of "Dos Rios" on the $19^{\text {th }}$ of May 1895(DE ARMAS, 2003, p. 8).Martí developed extraordinary thoughts on socio-political theory, national liberation and the humanistic character of the future Cuban republic. His ideas and morals made a major contribution to the formation of the "revolutionary-democratic" program. In addition, his ideals paved the way for the 1895-1898 revolution against the colonizers of Cuba. Martí himself was not a Marxist rather he is considered to be a romantic idealist influenced by the idealism of Hegel (AGRAMONTE, 2014, p. 66), (KRAPIVIN, 1985, p. 78). Readers unfamiliar with the Cuban revolution might ask: how is it possible then that Jose Martí was heavily reflected in Cuba's socialist and Marxist ideals. To begin with, Martí's proposed solutions for sociopolitical and economic contradictions were absolutely materialist. For example, in his elucidation of the dilemma of historical development he states: Only through studying the particularities and characteristics of every society is it possible to create a future social organization that assures real equality and development of human personality (ORRILLO, 2011, p. 90). Although Martí used a poetic language, he acknowledges the working class as an essential revolutionary force when he said "They are blessed among us [...] they are the vanguards of our liberty” (ORRILLO, 2011, p. 43). Nevertheless, Martí commented on the death of Marx by writing: "Marx deserves to be honored since he was on the side of the oppressed and he dedicated his thoughts to improve the lives of the poor" (RODRIGUEZ, 2014, p. 82). Jose Martí was not an economist but during his long stay in the United States of America he formulated his criticism of what he called "North American consumeristic culture"(PINO, 2015, p. 125). In his writings and articles, he acknowledged that class struggle is one of the main conflicts in the United States of America and he framed his vision on how consumerism oppresses the masses"(PINO, 2015, p. 129). He goes further analyzing how money corruption reduces values among masses and results in a deformed human being” (PINO, 2015, p. 138). In other analyses on the educational themes in the Americas, he criticizes the unequal access to educational institutions in the United States by concluding the following: "Most schools have beautiful campuses and monuments while others are just dim...yet they lack access to the people who desire to study in them" (ALMENDROS, 2015, p. 43). Not to mention, he also wrote about the dangers of North American imperialism that will face Latin America after the struggle of decolonization (ORRILLO, 2011, p. 43). On his vision for the future Cuba he mentions: as 
long as there is no poor men, as long as they are not lazy...then justice is achieved. Analyzing Martís poetic vision on economics leads to the following interpretation: Martí was against the theories of Spenser on economics and he rejected the happiness of individuals in its Lutheran and Keynesian sense of view (RODRIGUEZ, 2014, p. 92). In addition, he was influenced by the doctrines of utilitarianism of Bentham and the economics of Franklin. For the Cuban poet, a human community should be based on reason and this reason should be collective. In his philosophy the "I" has no significance. The importance is

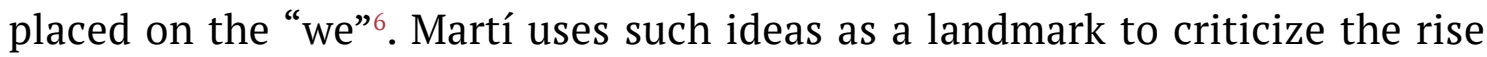
of isolated superior human identities. In his thought, human liberation could only be achieved when racism is defeated; he wrote in his work "My race": "Humans are more than white, brown and black" (ORRILLO, 2011, p. 123).

To sum it up, José Martís poetic and general writings on issues of class struggle, capitalism, colonialism, collectivism, human dignity and social justice made it suitable for the Cuban revolution to adopt his ideals.

\section{The abstract notion of human dignity and the Cuban revolution}

One cannot separate the theoretical work presented by Fidel Castro and Ernesto Che Guevara on human dignity. Being inspired by Marxist concepts and traditions on the development of human society, the leaders and intellectuals of the Cuban revolution theorized their own perspectives regarding dignity. Ernesto Guevara debates in his book "Man and socialism in Cuba" that capitalist "spokesmen" tend to wage an ideological war against socialism and Marxism. This ideological attack is composed of a set of assumptions by such spokesmen: Building socialism in Cuba was based on the destruction of the "individual" for the sake of the state (GUEVARA, 1967, p. 13). This brings us back to the classic anti-Marxist arguments which liberal critics employ who favor individualism over collectivism. However, Guevara argues that the individual was the main element that led to the revolution. The idea of the revolution prevailed in each individual's mind that belonged to the proletariat (GUEVARA, 1967, p. 15). Right from the beginning of the Cuban revolution the focus was on how to build the "future man". The concept of a future human that is free from cold capitalist ideals that are shaped by the law of value (GUEVARA, 1967, p. 20). Guevara argues the importance of liberating individuals from "the space of wolves who arrives only at the expenses of the failure of others". In addition, he notes that at the time it was 
impossible for the masses to resolve the contradiction between the guerrillas and the petit bourgeoisie, if they did not believe in the mentioned principles of individual liberation and collectivism (GUEVARA, 1967, p. 16). On the other hand, he argues that to build communism a complete education of work and culture should be achieved. This should be simultaneously created with the new man and a solid material base. Thus Guevara notes: "Freedom will be achieved based on Marxism when individuals truly attain full human conditions to produce without being compelled by the physical necessity of selling themselves as a commodity" (GUEVARA, 1967, p. 23). It is obvious that Che Guevara is in total agreement with Antonio Gramsci on his view on the necessity of a new educational culture as a must for a new communist society. Likewise, it is interesting to note the existing synergies between Guevara and Paulo Freire, as to the formation of a new educative culture. Both stress the necessity for implementing a new educative culture that would terminate the circle of oppression and greed in society.

Fidel Castro wrote a discourse titled "Dialogue of civilizations" as a response to the theory of the "clash of civilizations". In his response, Castro defines human rights as: right to human dignity as a human being. In addition in Castro's point of view "right to know dignity “ is composed of : right to learn, right to be treated equally, right to be independent and the right to be sovereign as a nation(CASTRO, 2007, p. 9). This implies the construction of a new civilization, economy and political structure from the base within collective solidarity (ACOSTA, 2013, p. 23). Castro argues Capitalist civilization favored consumerism, individualism and aggressive accumulation of wealth. In order to restore human dignity, society should not worry about increasing mass production but should aim for a form of production that preserves human dignity (ACOSTA, 2013, p. 25). Fidel argues that education has been the main essence in their efforts to fortify human dignity. Furthermore, education is necessary in this sense of view since human beings are born as a bundle of instincts and through education values are instilled into humans (CASTRO, 2007, p. 10). Castro offers a concrete example for how human dignity could be preserved through equal treatment and the right to free access to healthcare and education: "Health care and education in Cuba bring in zero GNP; moreover, everything produced by television is commercial free and brings in zero GNP. Fidel states that one should analyze how to measure value in respect to wealth and quality of life. Definitely quality of life and human dignity should not appear in any GNP”. 


\section{The concept of human dignity in the Cuban Constitution}

The Preamble of the Cuban Constitution (1976) states (FALK; MILAGROS; TORRAS, 2018, p. 7):

“WE DECLARE José Martí's desire, at last accomplished: "I want the first law of our Republic to be the worship of Cubans to the full dignity of man our will that the law of laws of the Republic is presided by this profound;"

“DECLARAMOS anhelo, al fin logrado, de José Martí: 'Yo quiero que la ley primera de nuestra República sea el culto de los Cubanos a la dignidad plena del hombre nuestra voluntad de que la ley de leyes de la República esté presidida por este profundo ${ }^{7}$;" The Cuban constitutional history has had three important stages with landmark changes in 1940, 1976 and 1992. But only the 1976 Constitution contains direct reference to Martí. The 1992 reform did not change the wording that refers to Martí. However, article 1 was changed and now states" (FALK; MILAGROS; TORRAS, 2018, p. 8).

"Cuba es un Estado socialista de trabajadores, independiente y soberano, organizado con todos y para el bien de todos, como república unitaria y democrática, para el disfrute de la libertad política, la justicia social, el bienestar individual y colectivo y la solidaridad humana ${ }^{8}$."

"Cuba is a socialist state of workers, independent and sovereign, organized with all and for the greater wellness of all, as a unitary and Democratic republic, for the enjoyment of political freedom, social justice, individual and collective well-being and human solidarity."

Since the Cuban Constitution is not justiciable and there is no constitutional defense mechanism like a special organ that is not linked to the Parliament, the range of human dignity has to be deduced from its function as a constitutional value and principle.

The normative force of the Cuban Constitution is therefore limited and there is no practice of direct application by judicial organs ${ }^{9}$. However, it can be noted that most judges have directly applied the Constitution to a legislative void or as an accompanying rule (HERNANDEZ, 2015, p. 137).

The strong emphasis on dignity but yet a weak constitutional force can only be explained by the socialist logic the Constitution is based upon: in a state "for the greater wellness of all" (Art. 1 of the Cuban Constitution 1976) and in the historical context of the seventies when the Constitution was born it was not imaginable that there exist articles and laws that were developed in the spirit of the constitutional values and principles that at the same time could violate 
the same principles and values (HERNANDEZ, 2015, p. 138) . Therefore, the Constitution remained as a normative reference to the socialist legality (TABIO, 1977, p. 377) and the Preamble functions as an axiological reservoir of principles and values (HERNANDEZ, 2015, p. 141).

\section{Implementation of the abstract notion of dignity in Cuba}

When the notion of human dignity was brought to a constitutional context, the Cuban people were slowly recovering from what they had experienced as the oppression of a whole people. The political context that had let to the Revolution 1959 was a struggle not only against capitalist influences from abroad but also against the own Bourgeoisie, since it was tied to the Spanish and US Bourgeoisie. Cuba had not been fully independent. The political system had not even had enough force to protect its own Bourgeoisie, not to speak about the workers. Therefore, in the struggle of the Revolution Cubans developed a negative definition of dignity in a political context: human dignity is not what they had experienced in the past.

The non-constitutional government from 1959 to 1975 and the constitutional institutionalization of the socialist system in 1976 can be seen as a response to that situation. In other countries, like France or the United States, when struggles for human rights took place, the historical situation was different in such a way that these people had suffered individual oppression by the state. But the unique collective oppression that was experienced in the fifties by the Cuban people led to a strong emphasis on sovereignty, equality and the development of a different political system in a collective sense.

Since the former government that was tied to Spain and the United States of America had not been able to guarantee the rights to the people, the solution was seen in the sovereignty of the state. Cuba's commitment to its sovereignty does not only shape its domestic policy but also it has a strong impact on its foreign policy, which seeks to defend the sovereign rights of all nations.

Cuba has a form of nationalism that reflects a spirit of international solidarity. Cubans consider for example their international medical missions to be an important expression of what Cuba offers in terms of international solidarity. Also the Preamble of the Constitution states: “GUIDED by the ideology of José Martí, and the socio-political ideas of Marx, Engels, and Lenin; [...] SUPPORTED by proletarian internationalism, by the fraternal friendship, aid, cooperation, and solidarity of the peoples of the world, especially those of Latin America and the Caribbean"(FALK; MILAGROS; TORRAS, 2018, p. 7). 
The Constitution dedicated the whole chapter 11 to equality. It states for example in article 42: Any discrimination based on race, gender, ethnicity, religious belief, national origin or any other discrimination that violates human dignity is a crime persecuted by the law. State institutions educate the population since an early age on the principles of equality among all human beings. Hence, discrimination and inequality are seen as violations of human dignity (FALK; MILAGROS; TORRAS, 2018, p. 19).

Article 43 reaffirms that: "The State establishes the right, won by the Revolution, of its citizens, without distinction based on race, color, sex, religious beliefs, national origin, or any other type offending human dignity to: [...]”. In the following the article lists equal access to work and public services (FALK; MILAGROS; TORRAS, 2018, p. 19).

This article reflects the view that treatment in conformity with human dignity had been regarded as absent before the revolution mainly due to institutionalized inequality.

The concept of dignity is conceived by the concept of equality and not by freedom, since individual freedom threatens the political freedom of the majority according to the socialist view. Socialist democracy was conceived as a democracy of and for the great majorities (exploited and marginalized) or as a democracy of the proletariat and of the peasantry fundamentally, sectors that at this time demanded the greatest vindications (HERNANDEZ, 2015, p. 138).

This was also made clear by the proclamation of the Constitution 1976 when the then second secretary of the Cuban Communist Party, Raúl Castro Ruz, pronounced: Socialism is a social regime in which the working class, in alliance with the other classes and working layers, it exerts its dominion and its dictatorship and, therefore, the freedoms are restricted for the minorities that try to harm the interests of the majorities and that affect socialism (CASTRO, 1976, p. 129).

Consequently, the new political system had to respond to institutionalized inequality. Representative democracy was not seen as a dignified process, since it facilitated the control of a small privileged group. Instead, Cubans developed a system of "indirect elections" or "popular democracy". It has representative elements as people are nominated and elected in voting districts. The pyramid-like voting system, modeled after the Leninist conception of "democratic centralism" concludes in the national assembly, which votes the Council of State that elects the President, in Cuba is characterized by representative elements and a system of approval by the Cuban people ${ }^{10}$. Also, the important mass organizations like the union of women, students, 
peasants, workers etc. are characterized by the same structure of electing delegates. The head figures of these organizations are well known public figures who participate in public discourse. Also, Cubans are related to the candidates in their voting districts and there is no such thing as election campaigns or money/funding in campaigns. Through this system the Cuban revolutionary government asks for the support of its people for the execution of the distribution of public goods according to the need according to support the Revolution. The objective of the socialist state is to protect the majority and the exploited working class. This does not mean equality in everything, but commitment to the social and economic rights of all, including access to education, health care, nutritional needs, and adequate housing. All are not equal, for not all have the same income or the same size house. But everyone has full access to education and health care and minimal food and housing, not conditioned by their capacity to pay. As they say in Cuba, "no one is left to their fate". As art. 1 of the Constitution puts the aim: the Cuban socialist state [...] is with all and for the greater wellness of all.

Although dignity was declared as the "first law" of the Republic, it could not take rank of other values and principles such as equality, political sovereignty, independence, or threaten the achievements of the revolutionary process (HERNANDEZ, 2015, p. 145), therefore the implementation of the abstract notion of dignity has to be seen in the constitutional and political protection of sovereignty, equality and the development of a revolutionary political system.

\section{Conclusion}

Preserving human dignity was one of the main slogans raised by the Cuban revolution; moreover, in the first revolutionary constitution in 1976 the Cuban state stressed on combining Martían and Marxist concepts of human dignity. Thus, for a better examination for the Cuban abstract notion of human dignity this article discussed both legal and socio-political aspects that reflected the perceptions of human dignity in Cuba. In addition, a panoramic overview of human dignity from a Marxíst point of view was provided. Accordingly, this paper debated the work of Marx and some of his opponents reviving the classical debate between liberal individualism and collectivism. In addition, the paper discussed the work of other Marxist authors such as Antonio Gramsci, Vladimir Lenin and Paulo Freire in order to provide a better understanding of Marxist concepts on human dignity. The paper formulated a genuine explanation as 
to the reason behind merging Martían and Marxist concepts of human dignity (judicially and politically). Furthermore, for a deeper synthesis of the Cuban revolutionary ideology and matters of human dignity, the article discussed two classic writings by the leaders of the Cuban revolution Fidel Castro and Ernesto Che Guevara. Analyzing the constitution, it was stressed that despite its nonjudiciability the concept of human dignity plays an important role as "the first law of the Republic" as stated in the Preamble. In the light of this background the article offered an explanation of the Cuban collective sense of human dignity that politically and legally has its emphasis on the concepts of sovereignty, equality and the establishment of an alternative political system.

\section{References}

A \& E Television Networks. Fidel Castro Biography. 2018. Disponible en: https:// www.biography.com/people/fidel-castro-9241487. Accessed: 29 Jun. 2018.

ACOSTA, Alberto. Otra economía para otra civilización. Temas, La Habana, n. 75, p. $21-28$, jul./sep. 2013.

AGRAMONTE, Roberto. Marti y el mundo de lo colectivo. Revista de la Universidad de la Habana, La Habana, CU, n. 277, p. 66 - 82, 2014.

ALMENDROS, Hermino. Ideario pedagógico Jose Marti: selección e introducción. La Habana: Centro de Estudios Martianos, 2015.

CONSEJO DEL PARTIDO COMUNISTA DE CUBA. Acuerdo del Consejo de Ministros y del Buró Político del PCc, de 22 de octubre de 1974, nombrando una Comisión Mixta del Partido y del Gobierno encargada de preparar y redactar el Anteproyecto de Constitución. Gaceta Oficial Extraordinaria, n. 13, de 23 de octubre de 1974.

BYRON, Christopher. A Marxian concept of human nature in defense of alienation: a revolutionary exegesis of a revolutionary philosophy. 2012. (Honors in the Major Program in Philosophy) - University of Central Florida, Orlando, 2012.

CASTRO, Fidel. Dialogue among civilizations. Habana: Oficinas de Publicaciones del Consejo de Estado, 2007.

CASTRO, Ruz Raul. Proclamación de la Constitución celebrado en el teatro Carlos Marx, de La Habana, el día 24 de febrero de 1976. Revista Cubana de Derecho, [S.l.], n. 11, p. 125 - 140, ene/jun. 1976.

CORNU Auguste. Carlos Marx \& Federico Engels. Habana: Instituto del Libro 1967.

DE ARMAS Ramon. Jose Marti Froger of peoples. Habana: Centro de Estudios Martianos, 2003. 
EMRAKOVA Alicia; VOLKOV Ratnikov. ¿Que Son las Clases y la Lucha de Clases?. Moscú: Editorial Progreso, 1986.

FALK, Pam; MILAGROS, Gavilan; TORRAS, Anna. Cuba's Constitution of 1976 with Amendments through 2002. Oxford: Oxford University Press, 2018.

FORGACS, David. The Gramsci reader selected writings 1916-1935. New York: University Press, 2000.

FREIRE, Paulo. Pedagogy of the Oppressed. Mexico City: Continuum International Publishing Group, 2005. First published Pedagogia del Oprimido.

GUEVARA, Ernesto. Man and Socialism in Cuba. Havana: Guairas Book Institute, 1967. First published El Socialismo y El Hombre en Cuba.

HERNANDEZ, Yan Guzmán. La dignidad como “Ley primera de nuestra República” y “con todos y para el bien de todos": dos deberes dialécticos desde la axiología martiana en la Constitución cubana. Revista Derecho del Estado, Colombia, n. 34, p. 127 - 151, ene./jun. 2015.

KRAPIVIN, Krapivin. ¿Qué es el materialismo dialéctico?. Moscú: Editorial Progreso, 1985.

LENIN, Vladimir. El estado y la revolución. Moscú: Editorial Progreso, 1977. (Obras escogidas en doce tomos, t. 7).

LEVECHENKO, T. Los pueblos de la URSS y Cuba marcharan siempre juntos: documentos sobre la amistad Soviético-Cubano. Moscú:Ediciones Pravada, 1963.

MOLINA, Ernesto. Devenir del modelo economico socialista. Habana: Editorial de Ciencias Sociales, 2016.

NOVACK, George. Introducción a la lógica: lógica formal y lógica dialéctica. Barcelona: Editorial Fontamara, 1979.

ORRILLO, Winston. Martí y Mariátegui: literatura, inteligencia y revolución en América Latina. Habana: Centro de Estudios Martíanos, 2011.

PALOS Ana; GONZALEZ, José Luis. Cuadernos de la cárcel Antonio Gramsci. México: Ediciones Era, 1984.

PINO, Alicia. Martí Miradas de fin de siglo. Habana: Editorial José Martí, 2015.

RODRIGUEZ, Carlos. Jose Marti, contemporáneo y compañero. Revista de la Universidad de la Habana, La Habana, CU, n. 277, 2014. p. 82 - 104.

RUMIANSTEV, Aleksei. Comunismo científico: diccionario. Moscú: Editorial Progreso, 1981.

SIERRA, Jerry. José Martí: apostle of Cuban Independence. 2015. Desponible en: http://www.historyofcuba.com/history/marti/marti.htm. Accessed: 2 Jul. 2018. 
TABIO, Fernando Álvarez. Política y legalidad. La Habana: Ciencias Sociales, 1977. P. 130 - 148.

VAN HERPEN, Marcel. Marx and Human Rights: analysis of an ambivalent relationship. Maastricht, Holanda: Cicero Foundation, 2012. (Great Debate Paper, 4).

\section{Notes}

${ }^{1}$ Bachelors of Political science, Lebanese American University.Master in International studies (emphasis on Peace Studies), University of Queensland, Australia. Currently, PhD candidate in Philosophy at the University of Havana Faculty of History and Philosophy e-mail: soltanhamadeh@gmail.com

${ }^{2}$ Studied Law in Germany, South Africa, Costa Rica and the United Kingdom. Graduated. London Metropolitan University (LL.M. International Law). Currently PhD candidate in Law at Eberhard-Karls-University Tuebingen. Email: k-reiber@web.de Graduated. London Metropolitan University (LL.M International Law). Currently PhD candidate in Law at Eberhard-Karls-University Tuebingen

3José Julián Martí Pérez (1853-1895), author, poet, revolutionary philosopher, often referred to as the "Cuban Apostle of Independence" (SIERRA, 2015).

${ }^{4}$ Fidel Alejandro Castro Ruz (1926-2016), leader of the Cuban revolution, Prime Minister from 1959, President from 1976 to 2008, First Secretary of the Communist Party of Cuba from 1961 until 2011.

${ }^{5} \mathrm{Gramsci}$ argues that feudalism and capitalism provided the peasants a certain value of human dignity but it was limited to boundaries of the pre-existing social conditions of the system.

${ }^{6}$ Todos por todos (all for all).

${ }^{7}$ Translated by the authors.

${ }^{8}$ Translated by the authors.

${ }^{9}$ Such as the Físcalia General de la República or the Tribunal Supremo Popular.

${ }^{10}$ For further information on the Cuban electoral process see also 'Electoral process in Cuba'. Available in: http://mipais.cuba.cu/cat_en.php?idcat=77 \&idpadre=76\&nivel=2. Accessed: 7 feb. 2018. 